\title{
Knowledge and Consumer Behavior Related to Safe Practices of Food Handling
}

\author{
MSc. Graziela Alvarez Corrêa da Costa \\ Department of Nutrition, Faculty of Health Sciences, University of Brasilia, Brazil. \\ E-mail: graziela.alvarez@terra.com.br
}

Tel: 55-61-3107-1779

PhD. Rita de Cássia Akutsu (Corresponding Author)

Department of Nutrition, Faculty of Health Sciences, University of Brasilia, Brazil.

E-mail: rita.akutsu@gmail.com

Tel: 55-61-8107-0622

MSc. Lorenza R. dos Reis Gallo

Department of Nutrition, Faculty of Health Sciences, University of Brasilia, Brazil.

E-mail: lorenzagallo23@gmail.com

Tel: 55-61-9986-4501

PhD. Wilma Maria Coelho Araújo

Department of Nutrition, Faculty of Health Sciences, University of Brasilia, Brazil.

E-mail: wilma.araujo@terra.com.br

Tel: 55-61-9239-6955

Received: March 19, 2016 Accepted: April 5, 2016 Published: May 11, 2016

doi:10.5296/jss.v2i1.9191ＵRL: http://dx.doi.org/10.5296/jss.v2i1.9191 


\section{Abstract}

The purpose of this research was to analyze the perceptions and practices of participants involved in safe food handling. The sample was composed by 204 participants. To assess behavior, knowledge and psychosocial factors, the instrument used was divided in six topics: sociodemographic characteristics; behavioral measures regarding safe food production; measures about knowledge and practices in pest control and food purchase; Food Safety scale with two factors and Cronbach's alpha of 0.75; Credence declaration scale with three factors and Cronbach's alpha of 0.78, both scales with seven points, Likert type; Self-efficacy scale with one factor and Cronbach's alpha of 0.86, also Likert type with five points. A linear model of multiple variance analysis was used to evaluate if the variables gender, age, income, education and professional experience were used to determine the behavioral, knowledge and psychosocial measures. When the detected differences were significant, a post-hoc analysis was used with the Tukey adjustment. The knowledge about safe food production and food poisoning showed that $95.1 \%$ of participants consider very important hygiene precautions in food preparation in their homes; $30.4 \%$ of participants said that they or someone in their family have developed symptoms related to food poisoning in the last 12 months. The data obtained for self-efficacy showed significant differences for the variables gender, age and education. Women and college graduates replied that they Are Sure they Can Do That when asked about the execution of tasks that promote food safety. These results substantiate the need for educational initiatives tailored to develop the food safety knowledge and food-handling practices in Brasil.

Keywords: foodborne diseases, sanitization, consumer behavior, self-efficacy, behavior change

\section{Introduction}

It is known that diseases arising from food contamination are a worldwide occurrence and can result in outbreaks of various proportions. The Center for Food Safety and Applied Nutrition (CFSAN) reveals that Foodborne Diseases (FbD) are responsible for nearly 76 million sick individuals, 350.000 hospitalizations and 5.200 deaths annually (Adak, Long, \& O’brien, 2002; Mead et al., 1999).

In Brazil, official data indicate that food preparation in recent years has been responsible for about $40 \%$ of FbDs (Brasil, 2014). Some studies corroborate this information and the authors consider that these results are due to improper handling conditions in home kitchens and that the prevalence of these diseases in developing countries is even larger, since not all cases are reported to health and epidemiological surveillance- because symptoms are mild, most patients do not resort to health services (Almeida et al., 2008; Marchi, Baggio, Teo, \& Busato, 2011; Mayer \& da Silva, 2009; Welker et al., 2010).

Research has shown that the most common practices which lead to the occurrence of such affections are: (i) maintaining the food at temperatures that promote microbial growth; (ii) consumption of food from unsafe sources; (iii) contamination of fresh food; (iv) inadequate 
cooking or reheating; (v) cross-contamination; (vi) handler health status; (vii) handler hygiene habits Medeiros (Almeida et al., 2008; Scott, 2003).

When trying to understand the behavior of individuals regarding food safety, several studies have been developed considering variables such as attitudes, knowledge, habits, positive influence and daily practices on the choice, purchase and transportation of (Behrens et al., 2010; Sanlier, Bilici, Çelik, \& Memis, 2012; Yarrow, Remig, \& Higgins, 2009). Each consumer individually perceives the risk due to food consumption and that determines the precautions taken in preparing their meals.

The perception of risk depends on several factors, including the way in which participants gather and process information about a particular event, how they perceive the risk level associated with such event, as well as the personal experience with such risk (Hansen, Holm, Frewer, Robinson, \& Sandøe, 2003). On the topic of one not following the recommendations for safe food preparation, literature identifies a lack of correspondence between the consumer's level of knowledge and the (Byrd-Bredbenner et al., 2008) implementation of safe practices in residential kitchens (Leite, Machado, de Vasconcellos, \& de Carvalho, 2012; Mayer \& da Silva, 2009; Santos, Cordeiro, Bittencourt, \& Bortolozzo, 2011). However, this observation does not reduce the importance attributed to this knowledge, because it enables the consumer to make their decisions carefully, though behavioral changes have not necessarily been produced (Byrd-Bredbenner et al., 2008; Leite et al., 2012; Mayer \& da Silva, 2009).

Some authors (Byrd-Bredbenner et al., 2008) consider that aspects such as credence, attitudes, and knowledge of the benefits of the implementation of safe practices in food handling can have an important impact on the behavioral changes of the individuals regarding appropriate health practices.

Dela Coleta and Dela Coleta (Dela Coleta \& Dela Coleta, 2011) state that people do not always use logic and rationality in attributing causality to events. This reveals that in many situations the causal attribution process is "psycho-logical", i.e., is submitted to a personal logic, and varies depending on whether or not the expectation that the results of their actions are determined by their own actions (internal locus of control) or external factors that are not under one's control (external locus of control) may be independent, of self-efficacy (Cascio et al., 2014; Lefcourt, 2014). In addition, these authors report the relationship between people's behavior and constructs such as self-efficacy and locus of control (Baptista, Teodoro, Cunha, Santana, \& Carneiro, 2009).

Self-efficacy is currently understood as the ability to organize and put in practice the action plans necessary to achieve a certain result and the sensation of control over behavior and the environment. It does not necessarily correspond to real individual competence, but a priori to their judgment of the competences and the capacity that they will have to overcome the difficulties inherent to the task. It is noteworthy that the self-efficacy credence determines the initiation, maintenance and abandonment of strategies or behaviors (Bandura, 2004; Toral \& Slater, 2007). 
Another factor that has been investigated is locus of control - the individual's perception about the relationship between their efforts and the outcome of an event. It corresponds to the level where the individual believes that change is controlled by internal factors (his own control), external factors (powerful others), or even those determined by random factors (Byrd-Bredbenner et al., 2008). These constructs have been investigated separately and together to identify adherence to treatment of various diseases and with different strategies (Rodrigues \& Costa, 2013). Behavior change is a process in which people have different levels of motivation to change and at these levels individuals transit as in a continuous process. The Transtheoretical Model's change in behavior is delineated as a state of readiness or willingness to change, that can move from one level to another, or from one situation to another (Dias \& Pereira, 2009; Norcross, Krebs, \& Prochaska, 2011). In this sense, the Transtheoretical Model describes "behavior change as a process in which individuals' progress through a series of discrete phases or stages of change (Norcross et al., 2011).

These stages are classified into pre-contemplation, when the individual has no intention to change behavior; contemplation, when the individual begins to realize the need to change behavior at some point in the future; decision, when there is an initiative to change the behavior; action, when the individual has put change consciously into practice for less than six months; and maintenance, when changes have already been incorporated into the individual's routine for more than six months (Norcross et al., 2011). It is important to know the stage of readiness for behavior change so that strategies can be created to intervene in behavior harmful to the physical and mental health of individuals (Cattai, Hintze, \& Junior, 2010). Credence is one of the biggest barriers to the creation of change.

Self-efficacy is the judgments we make about the competence we have to successfully carry out a learning pursuit or a specific activity. Such self-efficacy, associated with the locus of control theory and the theory of stages of change, has been shown to be a powerful tool, indicator of behavior in health. It has been used as a predictor of motion in behavior change (Norcross et al., 2011; Toral \& Slater, 2007).

In fact, the health belief model of Ajzen-Fishbein (Contento \& Murphy, 1990) considers that individuals make rational decisions about their health behavior when they are aware of the associated problems, when they have some knowledge about them and know the risk involved in not changing their behavior.

Although there are few studies about the relation between self-efficacy and changes in consumer behavior regarding food safety, it is known that this variable was used by Prochaska et al. (Prochaska, DiClemente, Velicer, \& Rossi, 1992) as one of the movement predictors through the five stages of change . In this context, the objective of this research was to analyze the perceptions and practices of the participants regarding safe food handling.

\section{Methods}

The project was approved by the Research Ethics Committee of the Faculty of Health Sciences (Registration No. 140/10, CEP / FS). 


\subsection{Participants}

The sample was composed by professors and employees from the University of Brasilia, identified among civil servants from the Human Resources Secretariat (HRS) of the University of Brasília (UnB) by registration number, job description, gender, age and unit where the participants developed their activities. The population of civil servants was stratified, according to their (participants) educational level and career plan descriptions. The inclusion criteria for participants were: member working at Darcy Ribeiro / UNB campus and a civil servant or an outsourced employee.

To calculate the sampling plan, a pilot study was carried out with 29 civil servants distributed proportionally among educational strata. With the obtained results, it was possible to estimate the proportion of correct answers about the knowledge of food handling, necessary to calculate the sample size. A proportion of correct answers equivalent to 0.70 was estimated, based on the design of a stratified random sample. Considering a significance level of $5 \%$, the final sample size was equal to 204 participants (57 men and 147 women).

\subsection{Instruments}

To evaluate behavior, knowledge and psychosocial factors of the selected sample regarding appropriate practices in food handling, an instrument divided into six topics, based on validated instruments, was used (Byrd-Bredbenner et al., 2008; Leite et al., 2012; Odwin \& Badrie, 2008) plus issues relating to national legislation on food services (Brasil, 2004). The instrument was submitted to semantic analysis with ten subjects of similar educational level to the sample. The validation by the judges technique (Pasquali, 2009) was performed by five professionals from the science and food technology field.

The content of the instrument considered: (I) the sociodemographic characteristics (nine items) to characterize the population; (II) behavioral measures on Safe Food Production, Food Poisoning (nine items) to assess the self-declaration of behavior; (III) measures on knowledge and practices regarding Urban Pest Control and Food Purchases (five items) to investigate the degree of knowledge on topics that influence food safety and those who divulge them; (IV) a Food safety Scale (locus of internal, external and random control) with two factors (Health Maintenance and External Responsibility) and a 0.75 Cronbach's Alpha to verify to whom the responsibility of ensuring the transmission control of Foodborne Diseases (FbD) is given; (V) a Credence Statement Scale with three factors (Concern with Hygiene, Food Poisoning, and Susceptibility to Contamination) and a Cronbach's alpha of 0.78. Both scales with seven points, Likert type, ranging from strongly disagree to fully agree; (VI) a Self-Efficacy scale with one factor and a Cronbach's alpha of 0.86, called Behavioral Measurement Scale, to verify the importance attributed by respondents to the items selected to compose the factors; This scale, also Likert type, contains five points ranging from I'm sure I can't do this (1) to I'm sure I can do this (5) to check the level of confidence of respondents in their ability to handle food.

To assess the internal consistency of the items that constitute the scales, a Cronbach's alpha coefficient was established (Hair, Black, Babin, Anderson, \& Tatham, 2009). 


\subsection{Statistical Analyses}

A linear model of multiple variance analysis was used to evaluate if the demographic variables, gender, age, income, education and professional experience determine the behavioral, knowledge and psychosocial measures. When significant differences were detected, a post-hoc analysis was used with Tukey adjustment.

For all these tests, the SAS 9.2 software for Windows and SPSS 20.0 was used. For analysis purposes, we used a 5\% significance level.

\section{Results}

Considering the study proposal, 204 questionnaires were administered. The data indicate that among the participants $54.4 \%(n=111)$ were teachers, $72.1 \%(n=147)$ were female, $79.4 \%$ ( $n=162$ ) aged over 30 years, $54.4 \%$ graduated college. The Data of the average family income in Minimum Wages (MW), indicate that $60.8 \%(\mathrm{n}=124)$ of participants are in the group with remuneration above five MW (1MW = US \$ 240.93), are married (62.7\%, n= 128), Brazilians (98.5, $n=201$ ), share the house with up to five people (99\%; $n=202)$, and $90.2 \%(n=184)$ claim not having any professional experience related to the food area.

The participants were in Decision Stage, when there was an initiative to change the behavior $(\mathrm{m}=3.46)$.

The result of applying the preliminary assessment instrument of self-declaration regarding Safe Food Production and Food Poisoning indicated that for 95.1\% $(n=194)$ of participants, caution with hygiene in food preparation in their homes are considered very important. When asked to identify with whom they learned the initial caution with hygiene in food handling, in a list of 19 possibilities with concomitant marking, most participants said that they learned with their mother $(84.3 \%, \mathrm{n}=172)$, and in second place through television $(61.3 \%, \mathrm{n}=125)$.

Considering the occurrence of foodborne diseases, 30.4\% $(n=62)$ of the participants said that they or a family member developed symptoms related to food poisoning in the last 12 months. Among the affected, the most common symptom was diarrhea $(82.3 \% ; n=51)$. However, only $35.5 \%(n=22)$ considered that the food prepared at home would be the potential culprit for the appearance of outbreaks. Just over a third of participants $(36 \%, n=73)$ said they always prepare their meals. The others participants admitted that a relative (33\%, $n$ $=67)$ or a domestic worker $(18 \%, n=37)$ is in charge of handling the food at home.

The information of knowledge and practice of the participants concerning Urban Pest Control and Food Purchase are in Table 1. Women had significantly higher hits on this issue when compared to men. Young participants, with less than 20 years of age, showed the worst performance being significantly different from other age groups for both Urban Pest Control, and Food Purchase.

Participants with a High School Diploma or a Bachelor Degree were statistically different and had a higher proportion of correct answers than participants with a elementary education level for Control of Urban Pests and Food Purchase. 
Participants with an income higher than $20 \mathrm{MW}$ had significantly less knowledge than participants with income in the ranges 10 to $>20 \mathrm{MW}$ and 5 to $>10 \mathrm{MW}$, for the variable Urban Pest Control. In the item Food Purchase, the proportion of correct answers in the range of over $20 \mathrm{MW}$ was significantly higher than those in the ranges 5 to $>10 \mathrm{MW}$ and 2 to $>5$ MW. In addition, the proportion of correct answers considering people at income range 10 to $>20 \mathrm{MW}$ and $>2 \mathrm{MW}$ was significantly higher than the income range of 2 to $>5 \mathrm{MW}$.

The results of this study revealed that knowledge is significantly higher among participants with professional experience in the field, when compared with those without experience for the variable Urban Pest Control.

Table 1. Linear Model of Multiple Variance Analysis of Urban Pests and Food Shopping Control

\begin{tabular}{|c|c|c|c|c|c|c|}
\hline \multirow[b]{2}{*}{ Variables } & \multicolumn{3}{|c|}{ Control of Urban Pests } & \multicolumn{3}{|c|}{ Food Purchase } \\
\hline & Mean $^{*}$ & $\mathbf{F}$ & $\mathbf{P}$ & Mean * & $\mathbf{F}$ & $\mathbf{p}$ \\
\hline Sex & & 0.55 & 0.045 & & 6.68 & 0.0105 \\
\hline Male & $0.67^{\mathrm{a}}$ & & & $0.79^{\mathrm{a}}$ & & \\
\hline Female & $0.65^{\mathrm{b}}$ & & & $0.86^{\mathrm{b}}$ & & \\
\hline Age & & 6.17 & 0.001 & & 11.32 & 0.0001 \\
\hline$<20$ years & $0.45^{b}$ & & & $0.56^{\mathrm{b}}$ & & \\
\hline 20 a 29 years & $0.66^{\mathrm{a}}$ & & & $0.86^{\mathrm{a}}$ & & \\
\hline 30 a 39 years & $0.63^{\mathrm{a}}$ & & & $0.89^{\mathrm{a}}$ & & \\
\hline 40 a 49 years & $0.66^{\mathrm{a}}$ & & & $0.83^{\mathrm{a}}$ & & \\
\hline+50 years & $0 . .71^{\mathrm{a}}$ & & & $084^{\mathrm{a}}$ & & \\
\hline Education & & 4.17 & 0.016 & & 1.86 & 0.0126 \\
\hline Bachelor & $0.68^{\mathrm{a}}$ & & & $0,89^{\mathrm{a}}$ & & \\
\hline High school & $0.64^{\mathrm{a}}$ & & & $0,80^{\mathrm{b}}$ & & \\
\hline Elementary School & $0.55^{\mathrm{b}}$ & & & $0,72^{\mathrm{C}}$ & & \\
\hline Income in MW & & 2.88 & 0.024 & & 2.82 & 0.0264 \\
\hline$<2$ & $0.51^{\mathrm{c}}$ & & & $0.92^{\mathrm{a}}$ & & \\
\hline $2 a<5$ & $0.62^{\mathrm{a}, \mathrm{b}, \mathrm{c}}$ & & & $0.89^{\mathrm{a}, \mathrm{b}}$ & & \\
\hline $5 a<10$ & $0.70^{\mathrm{a}, \mathrm{b}}$ & & & $0.87^{a . b}$ & & \\
\hline $10 a<20$ & $0.73^{\mathrm{a}}$ & & & $0.83^{\mathrm{b}, \mathrm{c}}$ & & \\
\hline+ de 20 & $0.60^{\mathrm{b}, \mathrm{c}}$ & & & $0.77^{\mathrm{c}}$ & & \\
\hline \multicolumn{2}{|c|}{ Professional Experience } & 4.72 & 0.031 & & 0.05 & 0.8279 \\
\hline Yes & $0.69^{\mathrm{a}}$ & & & $0.85^{\mathrm{a}}$ & & \\
\hline No & $0.65^{\mathrm{b}}$ & & & $0.83^{\mathrm{a}}$ & & \\
\hline
\end{tabular}

* Means with different letters are statistically different 
In order to evaluate the psychosocial aspects (internal, external and random locus control) a Food safety Scale was applied with two factors: health maintenance and external responsibility (Table 2). The data indicate that, for this scale, most people believe their actions may be able to avoid the occurrence of Foodborne diseases, i.e., the external responsibility factor (external and random control locus) averaged far below the health maintenance factor (internal control locus). The Health Maintenance Factor had an average of 6.2, demonstrating that the participants Moderately agree with the statements presented for the item. For the external responsibility factor, most participants said they Disagree Slightly with the affirmative. It should be noted that the responses of the two factors are congruent (Table 2).

Table 2. Linear Model of Multiple Variance Analysis of Food Security Scale (Health Maintenance Factor; External Responsibility Factor)

\begin{tabular}{|c|c|c|c|c|c|c|}
\hline \multirow[b]{2}{*}{ Variables } & \multicolumn{3}{|c|}{ Maintaining Health } & \multicolumn{3}{|c|}{ External responsibility } \\
\hline & Mean $^{*}$ & $\mathbf{F}$ & $\mathbf{P}$ & Mean* & $\mathbf{F}$ & $\mathbf{p}$ \\
\hline Sex & & 4.823 & 0.029 & & 8.153 & 0.005 \\
\hline Male & $6.08^{\mathrm{a}}$ & & & $2.83^{\mathrm{a}}$ & & \\
\hline Female & $6.23^{\mathrm{b}}$ & & & $2.43^{\mathrm{b}}$ & & \\
\hline Age & & 0.003 & 4.229 & & 2.916 & 0.022 \\
\hline$<20$ years & $5.30^{\mathrm{b}}$ & & & $2.98^{\mathrm{abcd}}$ & & \\
\hline 20 a 29 years & $6.20^{\mathrm{a}}$ & & & $2.51^{\mathrm{abcd}}$ & & \\
\hline 30 a 39 years & $6.18^{\mathrm{a}}$ & & & $2.26^{\mathrm{c}}$ & & \\
\hline 40 a 49 years & $6.18^{\mathrm{a}}$ & & & $2.95^{\mathrm{d}}$ & & \\
\hline+50 years & $6.17^{\mathrm{a}}$ & & & $2.40^{\mathrm{abcd}}$ & & \\
\hline Education & & 0.208 & 0.812 & & 10.120 & 0.000 \\
\hline Bachelor & $6.27^{\mathrm{a}}$ & & & $2.85^{\mathrm{ab}}$ & & \\
\hline High school & $6.14^{\mathrm{a}}$ & & & $2.97^{\mathrm{ab}}$ & & \\
\hline Elementary School & $6.20^{\mathrm{a}}$ & & & $2.22^{\mathrm{C}}$ & & \\
\hline Income in MW & & 0.774 & 0.543 & & 4.213 & 0.000 \\
\hline$<2$ & $5.94^{\mathrm{a}}$ & & & $2.76^{\mathrm{abcd}}$ & & \\
\hline $2 a<5$ & $6.20^{\mathrm{a}}$ & & & $2.84^{\mathrm{abcd}}$ & & \\
\hline $5 a<10$ & $6.21^{\mathrm{a}}$ & & & $2.62^{\mathrm{abcd}}$ & & \\
\hline $10 a<20$ & $6.02^{\mathrm{a}}$ & & & $2.33^{\mathrm{abcd}}$ & & \\
\hline+ de 20 & $6.04^{\mathrm{a}}$ & & & $1.74^{\mathrm{e}}$ & & \\
\hline Professional Experience & & 5.748 & 0.017 & & 17.861 & 0.000 \\
\hline Yes & $6.78^{\mathrm{a}}$ & & & $2.22^{\mathrm{a}}$ & & \\
\hline No & $6.18^{\mathrm{b}}$ & & & $2.93^{\mathrm{b}}$ & & \\
\hline
\end{tabular}

* Means with different letters are statistically different 
Men and women agree moderately with the items proposed for the Factor, however women had higher average than men. Considering the external responsibility factor, the men Disagree Slightly with the Affirmatives while women Disagree Moderately, confirming the results obtained in the Health Maintenance Factor.

Significant differences were also found for the age variable. The younger individuals (under 20) indicate that they Agree Slightly with the items Health Maintenance Factor and differ from the rest. There are also differences in this Factor regarding the Professional Experience in the Field variable; those who have experience Fully Agree, with the items of the Factor, while those without work experience in the field Agree Moderately, showing that they believe that food safety is controlled by internal factors (under their own control).

Regarding the External Responsibility variable, participants with age between 30-39 years (Moderately Disagree) differing significantly from those between 40 and 49 years of age (Slightly Disagree). Still regarding the External Responsibility Factor, results show that those who have elementary education differ from the others and Disagree Moderately with factor items.

Those participants with income above 20 MW Moderately Disagree with the factor items and differ from the others. Those with professional experience in the field Completely Disagree, while the inexperienced Moderately Disagree and are significantly different from participants who have no experience. Therefore older Women, with professional experience, with high school diploma, or with Bachelor Degree attribute to themselves the safety control of the food that they consume.

The Credence Statement Scale had three factors: Concern about Hygiene, Food Poisoning and Contamination Susceptibility (Table 3). The Concern about the Hygiene Factor presented significant difference by sex, Age, High School Diploma and Professional Experience in the Field. Women with Elementary education and those who have professional experience in the are Completely Agree with the items of this Factor, while men who are less than 20 years old and have no professional experience in the field Moderately Agree (Table 3).

Table 3. Linear Model of Multiple Variance Analysis of Statement Beliefs Scale (Hygiene Concern factor; Food Poisoning factor; susceptibility to contamination factor)

\begin{tabular}{ccccccccccc}
\hline \multirow{2}{*}{ Variables } & \multicolumn{3}{c}{ Hygiene Concern } & \multicolumn{2}{c}{ Food Poisoning } & \multicolumn{3}{c}{$\begin{array}{c}\text { Contamination } \\
\text { Susceptibility }\end{array}$} \\
& Mean* & F & p & Mean* & F & p & Mean* & F & p \\
\hline Sex & & 11.087 & 0.001 & & 0.046 & 0.83 & & 15.336 & 0.000 \\
Male & $6.54^{\mathrm{a}}$ & & & $4.98^{\mathrm{a}}$ & & & $4.06^{\mathrm{a}}$ & & \\
Female & $6.83^{\mathrm{b}}$ & & & $4.97^{\mathrm{a}}$ & & & $4.22^{\mathrm{b}}$ & & \\
\hline Age & & 5.678 & 0.000 & & 1.988 & 0.98 & & 1.063 & 0.376 \\
$<20$ years & $5.87^{\mathrm{a}}$ & & & $4.84^{\mathrm{a}}$ & & & $4.03^{\mathrm{a}}$ & & \\
\hline
\end{tabular}




\begin{tabular}{|c|c|c|c|c|c|c|c|c|c|}
\hline \multirow[t]{2}{*}{ Variables } & \multicolumn{3}{|c|}{ Hygiene Concern } & \multicolumn{3}{|c|}{ Food Poisoning } & \multicolumn{3}{|c|}{$\begin{array}{c}\text { Contamination } \\
\text { Susceptibility }\end{array}$} \\
\hline & Mean* & $\mathrm{F}$ & $\mathrm{p}$ & Mean* & $\mathrm{F}$ & $\mathrm{p}$ & Mean* & $\mathrm{F}$ & $\mathrm{p}$ \\
\hline 20 a 29 years & $6.75^{\mathrm{b}}$ & & & $5.28^{\mathrm{a}}$ & & & $4.09^{\mathrm{a}}$ & & \\
\hline 30 a 39 years & $6.83^{b}$ & & & $4.84^{\mathrm{a}}$ & & & $3.99^{\mathrm{a}}$ & & \\
\hline 40 a 49 years & $6.72^{b}$ & & & $5.12^{\mathrm{a}}$ & & & $4.05^{\mathrm{a}}$ & & \\
\hline+50 years & $6.90^{b}$ & & & $5.09^{\mathrm{a}}$ & & & & & \\
\hline Education & & 3.69 & 0.027 & & 1.100 & 0.035 & & 0.114 & 0.892 \\
\hline Bachelor & $6.58^{\mathrm{ab}}$ & & & $4.59^{\mathrm{a}}$ & & & $4.28^{\mathrm{a}}$ & & \\
\hline High school & $6.60^{\mathrm{b}}$ & & & $4.90^{\mathrm{ac}}$ & & & $4.14^{\mathrm{a}}$ & & \\
\hline $\begin{array}{c}\text { Elementary } \\
\text { School }\end{array}$ & $6.88^{\mathrm{a}}$ & & & $5.10^{c}$ & & & $4.17^{\mathrm{a}}$ & & \\
\hline Income in MW & & 1.459 & 0.216 & & 1.253 & 0.290 & & 2.423 & 0.51 \\
\hline$<2$ & $6.78^{a}$ & & & $4.69^{\mathrm{a}}$ & & & $3.98^{\mathrm{a}}$ & & \\
\hline $2 \mathrm{a}<5$ & $6.75^{\mathrm{a}}$ & & & $5.13^{\mathrm{a}}$ & & & $4.35^{\mathrm{a}}$ & & \\
\hline 5 a $<10$ & $6.74^{\mathrm{a}}$ & & & $5.24^{\mathrm{a}}$ & & & $3.89^{\mathrm{a}}$ & & \\
\hline $10 \mathrm{a}<20$ & $6.87^{\mathrm{a}}$ & & & $4.96^{\mathrm{a}}$ & & & $4.35^{\mathrm{a}}$ & & \\
\hline+ de 20 & $6.85^{\mathrm{a}}$ & & & $4.97^{\mathrm{a}}$ & & & $3.92^{\mathrm{a}}$ & & \\
\hline $\begin{array}{l}\text { Professional } \\
\text { Experience }\end{array}$ & & 0.000 & 20.587 & & 5.023 & 0.026 & & 5.939 & 0.016 \\
\hline Yes & $6.88^{\mathrm{a}}$ & & & $5.10^{\mathrm{a}}$ & & & 4.17 & & \\
\hline No & $6.49^{\mathrm{b}}$ & & & $4.91^{\mathrm{b}}$ & & & 4.18 & & \\
\hline
\end{tabular}

* Means with different letters are statistically different

The Food Poisoning Factor presented significant difference for the Educational and Experience in the Field variables. Participants with Bachelor Degree and greater experience Completely Agree and those with less experience Slightly Agree with the items of this factor.

The Susceptibility to Contamination Factor presented significant difference for the Sex variable, although men and women Neither Agree nor Disagree with the items of this factor. For the Professional Experience in the field variable, both of them Neither Agree nor Disagree (with experience; without experience), although they are significantly different.

The instrument that evaluates Self-efficacy (Behavioral Measurement Scale) with a single factor shows that significant differences were found for the variables sex, age and education (Table 4). Women and those with Bachelor Degree answered that they Are Sure They can do This when asked about the implementation of tasks. The younger individuals (less than 20 years of age), on the other hand, said that they Can do or self-motivate consistently to do the tasks (Decision). 


\section{Macrothink}

Journal of Safety Studies

ISSN 2377-3219

2016, Vol. 2, No. 1

Table 4. Linear Model of multiple variance analysis of Self-efficacy scale of the participants

\begin{tabular}{|c|c|c|c|}
\hline \multirow[b]{2}{*}{ Variables } & \multicolumn{3}{|c|}{ Self-efficacy } \\
\hline & Mean $^{*}$ & Valor F & P-valor \\
\hline Sex & & 37.461 & 0.0001 \\
\hline Male & $4.35^{\mathrm{b}}$ & & \\
\hline Female & $4,54^{\mathrm{a}}$ & & \\
\hline Age & & 19.561 & 0.0001 \\
\hline$<20$ years & $4.08^{\mathrm{a}}$ & & \\
\hline 20 a 29 years & $4.52^{\text {bcde }}$ & & \\
\hline 30 a 39 years & $4.44^{\text {bcde }}$ & & \\
\hline 40 a 49 years & $4.50^{\text {bcde }}$ & & \\
\hline + 50 years & $4.59^{\text {bcde }}$ & & \\
\hline Education & & 9.531 & 0.0001 \\
\hline Bachelor & $4.57^{\mathrm{a}}$ & & \\
\hline High school & $4.39^{\mathrm{b}}$ & & \\
\hline Elementary School & $4.37^{\mathrm{b}}$ & & \\
\hline Income in MW & & 1.281 & 0.2805 \\
\hline$<2$ & $4.45^{\mathrm{a}}$ & & \\
\hline $2 \mathbf{a}<5$ & $4.43^{\mathrm{a}}$ & & \\
\hline 5 a $<10$ & $4.47^{\mathrm{a}}$ & & \\
\hline $10 a<20$ & $4.54^{\mathrm{a}}$ & & \\
\hline + de 20 & $4.62^{\mathrm{a}}$ & & \\
\hline Professional Experience & & 0.241 & 0.6248 \\
\hline Yes & $4.54^{\mathrm{a}}$ & & \\
\hline No & $4.48^{\mathrm{a}}$ & & \\
\hline
\end{tabular}

* Means with different letters are statistically different

Analyzing the items of the instrument it is possible to verify that the participants, even when informed about the risks to their health, were not capable of motivating changes such as checking the temperature of the refrigerator and freezer every month (20\%); using Styrofoam or thermal bag to keep cold the refrigerated or frozen items to be transported (12\%) and transfer products from larger containers to smaller ones before cooling them (12\%). 
On the other hand, during the implementation of this research instrument it was observed that some participants seemed to show willingness to change their behavior, even when they didn't know the food safety objective of some practices. This can be observed, for example, in the situation where $58.3 \%(n=119)$ of the participants said they were sure that they could change their behavior, starting to place raw meats on different shelves, away from food ready for consumption.

\section{Discussion}

The results showed that, in general, consumers had good knowledge about food safety, especially women, individuals with Bachelor degree, over 30 years old, with income above $20 \mathrm{MW}$. Those individuals attribute great importance to food hygiene, which corroborates to the findings of other studies (Garayoa, Córdoba, Garcia-Jalon, Sanchez-Villegas, \& Vitas, 2005). In relation to the importance given by the participants to hygiene in food preparation, the data from this study are in agreement with other studies which reported the role of relatives, represented by mothers and fathers, followed by the media's role in the dissemination and internalization of food safety issues (Odwin \& Badrie, 2008).

Regarding the occurrence of FbD and the manifestation of its symptoms, the participants did not recognize their food handling practices as potential food outbreak factors, corroborating to another study in which only $20 \%$ of individuals admitted the problem association with food prepared in their homes and their own practices (Odwin \& Badrie, 2008). Such findings disagree with Brazilian official data for the 1999-2004 period, indicating households as places with the highest occurrence of outbreaks (48.5\%) followed by restaurants (18.8\%) and schools (11.6\%) (Brasil, 2014).

They are also divergent from the results about the responsibility for meals preparation in a study conducted in the United States which showed that in a universe of young adults, 84\% ( $n=4343$ ) of them were responsible for preparing their own food (Odwin \& Badrie, 2008). This difference is possibly due to the caretaker role assigned to women in Brazilian society (Petrucci, Borsa, \& Koller, 2015).

It should be noted that food outbreaks anywhere in the world can be caused by a combination of factors such as lack of information, improper use of products and materials for cleaning, the use of the same utensils to prepare different foods (Authority, 2015). In this research, the items related to raw food storage in refrigerators and the storage of meal leftovers, still warm, were those who showed the lowest scores of correct responses, which is consistent with some studies that evidenced the consumer failures in storing food leftovers and raw food (Authority, 2015; Jevšnik et al., 2013; Low, Jani, Halim, Alias, \& Moy, 2016; Redmond \& Griffith, 2003).

The predominant result of the internal control locus in the Food Safety Scale may be associated to the results of the instrument that evaluates the knowledge and practices regarding Safe Food Production and Food Poisoning, which found that only 13.0\% of people believe that FbD outbreaks may have started in their home. While on the one hand the 
credence of the participants in their capacity to prevent FbD can be beneficial, on the other hand, it implicates neglecting an important risk factor in FbD transmission.

In this sense, it is worth noting the importance of the participants having been identified in the Decision stage, which favors the adoption of appropriate food handling practices having as staring point awareness and training (Garcia, de Cássia Akutsu, Savio, Camargo, \& Silva, 2015).

A study (Byrd-Bredbenner et al., 2008) showed results very close to this research. In it, the responsibility for food safety was attributed to the internal control locus by $54.9 \%$ of participants, followed by the external locus with $28.4 \%$, and the external randomized locus with $12.4 \%$. Another survey identified that $90.0 \%$ of the consumers perceived that the risk of developing a disease caused by a food prepared by them was very low; thus, $66.0 \%$ believed they had total or almost total control of food safety when preparing meals; $84.0 \%$ said they had full or almost full responsibility for the safety of their own food; $68.0 \%$ agreed that ultimately food producers were responsible for the safety of their food (Redmond \& Griffith, 2003).

On the other hand, a study verified that the majority of the respondents did not recognize food contamination as a personal threat- the scores ranged from 2.90 for men to 3.24 for women (Byrd-Bredbenner et al., 2008). In this sense, it is necessary to establish verification and dissemination strategies of the real sources of food contamination. This is due to the fact that although people realize they are the ones responsible for food protection, they don't realize that the food handled inside their home is responsible for FbDs.

Regarding self-efficacy, in this study it was observed that participants have high confidence in their ability to overcome challenging situations regarding behavioral change and in their ability to face temptations contrary to healthy change. However, it was still observed that the participants showed no motivation to monthly check the temperature of their refrigerator; to pack in suitable containers refrigerated food that will be transported; to transfer leftovers to smaller containers before placing them in the refrigerator, as basic food safety practices. In addition, the consumers were not motivated to refrain from eating raw eggs, which could surely be identified as a risk behavior.

Literature indicates that to prevent the contamination of food ready for consumption or prepackaged by raw foods, these should be arranged at the bottom of the refrigerator, whenever there is a need to store different foods in the same equipment (ABERC, 2013). Likewise, rapid food cooling after cooking minimizes the cross-contamination risk and maintains the food at temperatures that do not promote microbial growth (ABERC, 2013; Alimentarius, 1993).

Still regarding the answers given in the Behavioral Measurement Scale about safe food handling, it was found that the statements (i) lunch leftovers can be left on the kitchen counter until dinner time; and ii) Fruits or vegetables can be sliced on the same board that previously raw meat was cut and prepared were those that presented the highest percentage of disagreement. Procedures as those described in item (i) provide micro-organisms with the 
time and temperature required for their development. The micro-organism population may reach a number such that even high-temperature cooking is not able to reduce contamination, because the larger the population, the greater the possibility of having cells with higher thermal resistance (Franco \& Landgraf, 2003). In this case, it is important that this procedure is widely reported as inappropriate.

Although most of the participants disagree with the statement: ii) Fruit or vegetables can be sliced on the same board that previously raw meat was cut and prepared. It was found that, for items that evaluated the knowledge of safe practices, the item preparation was penalized mainly by the question that estimated consumer knowledge related to cross-contamination practices, in which the result showed a proportion of correct answers lower than 0.5.

In this research, a positive relationship between the participant's knowledge related to food safety and level of education was not identified, for the sanitization, food preparation, storage and temperature items. Some studies have shown that consumers with low educational level have a higher prevalence of risky behavior when compared to those with higher educational levels (Askarian, Kabir, Aminbaig, Memish, \& Jafari, 2004; Buccheri et al., 2007; Garayoa et al., 2005; Garcia et al., 2015). However, in this study this relationship was not confirmed.

The food handling, knowledge, attitudes, and self-reported practices of consumers, along with their actual food-handling behaviors, have been studied by various researchers over time. In all of these studies, consumers were found to be aware of some safe food handling practices but lacked knowledge of others. As such, it was concluded that consumer knowledge of food safety was inadequate and required improvement in most instances. Temperature control, especially in the case of defrosting frozen foods, is one of the areas which seem to present a major challenge in many societies. Still, a large proportion of consumers seem to either have lack of knowledge concerning adequate refrigeration temperatures or do not check the temperatures of their refrigerators. Awareness with respect to bacteria causing food-related illnesses was also found to be rather low (Aygen, 2012; Turnbull-Fortune \& Badrie, 2014).

Research conducted in Turkey showed that regarding age, those respondents younger than 20 years old seem to be the least knowledgeable on a variety of safe food handling practices. The older groups are more knowledgeable about these issues. Regarding knowledge and self-reported practices about food handling and food safety knowledge, many significant differences exist about education. Not surprisingly, knowledge and awareness of safe food handling practices increase along with the educational level. Besides this, responses to other questions on the questionnaire show that those who have elementary education consider "safe and hygienic conditions used in preparing food at home" to be less important than others with higher degrees. They have also experienced food-related illness within the past year more frequently when compared to college graduates (Aygen, 2012; Sanlier et al., 2012).

Although several other studies point to a different direction (Garcia et al., 2015; Meleko, Henok, Tefera, \& Lamaro, 2015; Nesbitt et al., 2014), the answers obtained through this study suggest that the participants do not recognize that proper food refrigeration is an attitude that benefits their health. Furthermore, $58.3 \%$ of the participants were willing to 
change their food handling practices, even when obvious to the underlying principles behind these changes, seeming to have an intuition that their practices are wrong.

Nevertheless, the participants are willing to change their habits and have confidence in their ability to do so. Women and participants with bachelor degree are statistically more confident in their ability to perform safe food handling practices, when compared to men and people with elementary and high school education. That is possibly due to gender issues identified with the role of women in the Brazilian society as the family caregiver, and thus responsible for the knowledge transmission of both preparation techniques and safe attitudes to be adopted (Petrucci et al., 2015).

\section{Conclusion}

To estimate reliability, Cronbach's alpha and Gutman lambda 2 were calculated, where values equal to or above 0.70 in both indicators were desired (Hair et al., 2009; Stevens, 2012), validating the three scales used in this research.

The instrument construction and validation, which identify the factors that affect the perception, attitudes, knowledge and practices regarding food safety, are important to choose intervention strategies to educate populations.

This research showed not only the characteristics and behavior of the studied population, but it also identified an important information asymmetry and lack of correspondence between the consumer's level of knowledge and the implementation of safe practices in residential kitchens. However, this asymmetry does not reduce the importance given to an appropriate knowledge on food safety, for the knowledge enables the consumer to make decisions in a better informed way, although it may not necessarily produce behavioral changes. In addition, to implement any educational project for handlers and consumers, it is important to know the target-group, identifying what consumers know about food safety and adequate household food handling practices.

According to the majority of the theories on cognitive behavior, cognitions like credence, control locus and self-efficacy locus have significant impact on whether or not recommended healthy behavior is adopted. In this sense, positive credence's - the confidence shown in safe food handling that is able to promote changes toward healthy behaviors - are important information for the adoption of educational strategies that address affective and cognitive factors.

This study suggests that despite culture differences worldwide it can be inferred that the education level is the most responsible for knowledge and safe practices in food handling at home. It is important to highlight that in the Brazilian culture women are responsible for feeding, cooking and plays a role as caretakers in the society. In this way educational strategies must be focused in women who are responsible for food safety practices.

\section{References}

ABERC. (2013). Manual Drafting Practices and Dining Services Collectivities. 
Adak, G. K., Long, S. M., \& O’brien, S. J. (2002). Trends in indigenous foodborne disease and deaths, England and Wales: 1992 to 2000. Gut, 51(6), 832-841.

Alimentarius, C. (1993). Code of hygienic practice for precooked and cooked foods in mass catering.

Almeida, Cristiane Falcão de, Araújo, Emmanuele de Souza, Soares, Yette da Cruz, Diniz, Rafael Loureiro das Chagas, Fook, Sayonara Maria Lia, \& Vieira, Karlete Vânia Mendes. (2008). Perfil epidemiológico das intoxicações alimentares notificadas no Centro de Atendimento Toxicológico de Campina Grande, Paraíba. Rev. bras. epidemiol, 11(1), 139-146.

Askarian, Mehrdad, Kabir, Gholamhosein, Aminbaig, Maria, Memish, Ziad A, \& Jafari, Peyman. (2004). Knowledge, attitudes, and practices of food service staff regarding food hygiene in Shiraz, Iran. Infection Control \& Hospital Epidemiology, 25(01), 16-20.

Authority, EFS. (2015). The European Union summary report on trends and sources of zoonoses, zoonotic agents and food-borne outbreaks in 2013. EFSa Journal, 13(1).

Aygen, F. G. (2012). Safe food handling: knowledge, perceptions, and self-reported practices of Turkish consumers. International Journal of business and Management, 7(24), 1.

Bandura, A. (2004). Health promotion by social cognitive means. Health education \& behavior, 31(2), 143-164.

Baptista, Makilim Nunes, Teodoro, Maycoln Leôni Martins, Cunha, Ricardo Vivian da, Santana, Priscilla Rodrigues, \& Carneiro, Adriana Munhoz. (2009). Evidência de validade entre o Inventário de Percepção de Suporte Familiar-IPSF e Familiograma-FG. Psicologia: reflexão e crítica, 22(3), 466-473.

Behrens, J. H., Barcellos, M. N., Frewer, L. J., Nunes, T. P., Franco, Bernadette DGM, Destro, M. T., \& Landgraf, M. (2010). Consumer purchase habits and views on food safety: A Brazilian study. Food control, 21(7), 963-969.

Brasil. (2004). RDC 216/2004. ANVISA.

Brasil. (2014). Sistema de informação de agravos de notificação em saúde (SINAN NET). Brasília: Minietério da Saúde -Departamento de Vigilância Epidemiológica.

Buccheri, Cecilia, Casuccio, Alessandra, Giammanco, Santo, Giammanco, Marco, La Guardia, Maurizio, \& Mammina, Caterina. (2007). Food safety in hospital: knowledge, attitudes and practices of nursing staff of two hospitals in Sicily, Italy. BMC health services research, $7(1), 1$.

Byrd-Bredbenner, Carol, Abbot, Jaclyn Maurer, Wheatley, Virginia, Schaffner, Donald, Bruhn, Christine, \& Blalock, Lydia. (2008). Risky eating behaviors of young adults-implications for food safety education. Journal of the American Dietetic Association, 108(3), 549-552. 
Cascio, Maura I, Magnano, Paola, Elastico, Silvia, Costantino, Valentina, Zapparrata, Valentina, \& Battiato, Antonino. (2014). The Relationship among Self-Efficacy Beliefs, External Locus of Control and Work Stress in Public Setting Schoolteachers. Open Journal of Social Sciences, 2(11), 149.

Cattai, Glauco Barnez P, Hintze, Luzia Jaeger, \& Junior, Nelson Nardo. (2010). Validação interna do questionário de estágio de prontidão para mudança do comportamento alimentar e de atividade física. Rev Paul Pediatr, 28(2), 194-199.

Contento, Isobel R, \& Murphy, Barbara Maksymowicz. (1990). Psycho-social factors differentiating people who reported making desirable changes in their diets from those who did not. Journal of Nutrition Education, 22(1), 6-14.

Dela Coleta, J. A., \& Dela Coleta, M. F. (2011). Conhecendo a si e ao outro: Percepção e atribuição de causalidade. Psicologia social: Principais temas e vertentes, 134-152.

Dias, R. B., \& Pereira, A. A. (2009). Diretrizes clínicas para atuação em saúde mental na atenção básica. Nescon/UFMG. Belo Horizonte: NESCON/UFMG.

Franco, Bernadette Dora Gombossy de Melo, \& Landgraf, Mariza. (2003). Microbiologia dos alimentos Microbiologia dos alimentos: Atheneu.

Garayoa, Roncesvalles, Córdoba, María, Garcia-Jalon, Isabel, Sanchez-Villegas, Almudena, \& Vitas, Ana Isabel. (2005). Relationship between consumer food safety knowledge and reported behavior among students from health sciences in one region of Spain. Journal of Food Protection ${ }^{\circledR}, 68(12), 2631-2636$.

Garcia, Paloma Popov Custódio, de Cássia Akutsu, Rita, Savio, Karin Eleonora, Camargo, Erika Barbosa, \& Silva, Izabel Cristina Rodrigues. (2015). The Efficacy of Food Handler Training: The Transtheoretical Model in Focus, Brazil, 2013. Journal of Safety Studies, 1(2), $11-26$.

Hair, J. F., Black, W. C., Babin, B. J., Anderson, R. E., \& Tatham, R. L. (2009). Análise multivariada de dados: Bookman Editora.

Hansen, Janus, Holm, Lotte, Frewer, Lynn, Robinson, Paul, \& Sandøe, Peter. (2003). Beyond the knowledge deficit: recent research into lay and expert attitudes to food risks. Appetite, 41(2), 111-121.

Jevšnik, M., Ovca, A., Bauer, M., Fink, R., Oder, M., \& Sevšek, F. (2013). Food safety knowledge and practices among elderly in Slovenia. Food control, 31(2), 284-290.

Lefcourt, H. M. (2014). Locus of control: Current trends in theory \& research: Psychology Press.

Leite, Luísa Helena Maia, Machado, Paula Aballo Nunes, de Vasconcellos, Ana Lúcia Ribeiro, \& de Carvalho, Idria Mendes. (2012). Boas práticas de higiene e conservação de alimentos em cozinhas residenciais de usuários do programa saúde da família-Lapa. Revista de Ciências Médicas, 18(2). 
Low, Wah Yun, Jani, Rohana, Halim, Hishamuddin Abdul, Alias, Abd Aziz, \& Moy, Foong Ming. (2016). Determinants of food hygiene knowledge among youths: A cross-sectional online study. Food Control, 59, 88-93.

Marchi, Débora Melyna, Baggio, Nayara, Teo, Carla Rosane Paz Arruda, \& Busato, Maria Assunta. (2011). Ocorrência de surtos de doenças transmitidas por alimentos no Município de Chapecó, Estado de Santa Catarina, Brasil, no período de 1995 a 2007. Epidemiologia e Serviços de Saúde, 20(3), 401-407.

Mayer, Laurí, \& da Silva, Wladimir Padilha. (2009). ANÁLISE DOS SURTOS NOTIFICADOS DE DOENÇAS TRANSMITIDAS POR ALIMENTOS NO ESTADO DE SÃO PAULO ENTRE 1995 E 2008. Revista Brasileira de Tecnologia Agroindustrial, 3(2).

Mead, Paul S, Slutsker, Laurence, Dietz, Vance, McCaig, Linda F, Bresee, Joseph S, Shapiro, Craig, . . . Tauxe, Robert V. (1999). Food-related illness and death in the United States. Emerging infectious diseases, 5(5), 607.

Meleko, Asrat, Henok, Andualem, Tefera, Worku, \& Lamaro, Tafesse. (2015). Assessment of the Sanitary Conditions of Catering Establishments and Food Safety Knowledge and Practices of Food Handlers in Addis Ababa University Students' Cafeteria. Science, 3(5), 733-743.

Nesbitt, Andrea, Thomas, M Kate, Marshall, Barbara, Snedeker, Kate, Meleta, Kathryn, Watson, Brenda, \& Bienefeld, Monica. (2014). Baseline for consumer food safety knowledge and behaviour in Canada. Food Control, 38, 157-173.

Norcross, J. C., Krebs, P. M., \& Prochaska, J. O. (2011). Stages of change. Journal of clinical psychology, 67(2), 143-154.

Odwin, R., \& Badrie, N. (2008). Consumers' perceptions and awareness of food safety practices in Barbados and Trinidad, West Indies-a pilot study. International Journal of Consumer Studies, 32(4), 394-398.

Pasquali, L. (2009). Instrumentação psicológica: fundamentos e práticas: Artmed Editora.

Petrucci, G. W., Borsa, J. C., \& Koller, S. H. (2015). Understanding and Contextualizing Parenting in Brazil. Contemporary Parenting: A Global Perspective, 46.

Prochaska, J. O., DiClemente, C. C., Velicer, W. F., \& Rossi, J. S. (1992). Criticisms and concerns of the transtheoretical model in light of recent research. British Journal of Addiction, 87(6), 825-828.

Redmond, E. C., \& Griffith, C. J. (2003). Consumer food handling in the home: a review of food safety studies. Journal of Food Protection ${ }^{\circledR}, 66(1), 130-161$.

Rodrigues, Â., \& Costa, E. V. (2013). Locus de controlo, auto-eficácia e qualidade de vida na diabetes tipo 1. Psicologia, Saúde \& Doenças, 14(3), 389-404.

Sanlier, N., Bilici, S., Çelik, B., \& Memis, E. (2012). Food safety knowledge and practices of nursing students. Italian Journal of Food Science, 24(1), 86. 


\section{Macrothink}

Journal of Safety Studies

ISSN 2377-3219

2016, Vol. 2, No. 1

Santos, MHR, Cordeiro, AR, Bittencourt, JVM, \& Bortolozzo, EQ. (2011). Segurança alimentar na manipulação domestica, abordagem física, química e biológica. III Simpósio de Segurança Alimentar, Florianópolis: mai.l jun, 42-47.

Scott, E. (2003). Food safety and foodborne disease in 21st century homes. The Canadian Journal of Infectious Diseases, 14(5), 277.

Stevens, J. P. (2012). Applied multivariate statistics for the social sciences: Routledge.

Toral, N., \& Slater, B. (2007). Abordagem do modelo transteórico no comportamento alimentar. Ciênc. saúde coletiva, 12(6), 1641-1650.

Turnbull-Fortune, S., \& Badrie, N. (2014). Practice, Behavior, Knowledge and Awareness of Food Safety among Secondary \& Tertiary Level Students in Trinidad, West Indies. Food and Nutrition Sciences, 5(15), 1463.

Welker, Cassiano Aimberê Dorneles, Both, Jane Mari Corrêa, Longaray, Solange Mendes, Haas, Simone, Soeiro, Mara Lúcia Tiba, \& Ramos, Rosane Campanher. (2010). Análise microbiológica dos alimentos envolvidos em surtos de doenças transmitidas por alimentos (DTA) ocorridos no estado do Rio Grande do Sul, Brasil. Revista Brasileira de Biociências, $8(1)$.

Yarrow, L., Remig, V. M., \& Higgins, M. M. (2009). Food safety educational intervention positively influences college students' food safety attitudes, beliefs, knowledge, and self-reported practices. Journal of environmental health, 71(6), 30-35.

\section{Copyright Disclaimer}

Copyright for this article is retained by the author(s), with first publication rights granted to the journal.

This is an open-access article distributed under the terms and conditions of the Creative Commons Attribution license (http://creativecommons.org/licenses/by/3.0/). 